\title{
ОСНОВНІ АСПЕКТИ РЕАБІЛІТАЦІЇ СТУДЕНТСЬКОЇ МОЛОДІ ЗІ СКОЛІОТИЧНОЮ ПОСТАВОЮ
}

\author{
Куц-Бурдейна О. О.
}

\section{ВСТУП}

Дослідження, які стосуються вивчення стану здоров'я студентської молоді, свідчать про тенденцію зниження фізичної і функціональної підготовленості. За останні десятиліття збільшилася кількість студентів, віднесених за станом здоров'я до спеціальної медичної групи. Одним із чинників, який негативно впливає на функціональні можливості організму, а також сприяє виникненню деяких хронічних захворювань, виступає дисбаланс розвитку опорно-рухового апарату, який може проявлятися порушенням постави ${ }^{1}$.

Розповсюдженість порушень постави у студентів зумовлена складністю організації роботи і відсутністю оптимальних методик фізичного виховання у закладах вищої освіти. Як відомо, у закладах вищої освіти кількість студентів 3 порушенням постави збільшується з кожним роком, що зумовлено низькою мотивацію молоді до занять фізичною культурою².

На жаль, фізичні вправи, які використовуються для корекції постави, передбачають головним чином їх вплив на морфологічні особливості опорно-рухового апарату. При цьому застосовуються хореографічні і гімнастичні вправи, вправи з використанням фітболів

${ }^{1}$ Альошина А., Колос М. Корекція функціональних порушень опорно-рухового апарату студентів у процесі фізичного виховання. Фізичне виховання, спорт $i$ культура здоров'я у сучасному суспільстві : зб. наук. пр. Східноєвроп. нац. ун-ту ім. Лесі Украӥнки / уклад. А.В. Цьось, С.П. Козіброцький. Луцьк : Східноєвроп. нац. ун-т ім. Лесі Українки, 2015. № 4(32). С. 52-56; Кашуба В.А., Носова Н.Л., Дудко М.В., Одноралова Н.А. Визуальный скрининг биогеометрического профиля осанки студентов в процессе физического воспитания. Сучасні біомеханічні та інформаційні технологї у фізичному вихованні і спорті : матеріали III Всеукр. електронної конф. (Київ, 18 червня 2015 р.). Київ : НУФВСУ, 2015. С. 72-76; Дудко М.В. Характеристика состояния биогеометрического профиля осанки и физической подготовленности студентов в процес се физического воспитания. Физическое воспитание студентов. 2015. 0;4. С. 30-35.

${ }^{2}$ Дудко М.В. Характеристика состояния биогеометрического профиля осанки и физической подготовленности студентов в процес ее физического воспитания. Физическое воспитание студентов. 2015. 0;4. С. 30-35.

Куц-Бурдейна О., Фурман Ю. Вплив бігових навантажень на функціональну підготовленість студенток з порушенням постави. Спортивна наука Украӥни. 2017. № 1(77). C. 38-42. 
та вправ східної гімнастики, елементів калланетики. Однак слід зазначити, що деякі дослідники використовували вправи, які були спрямовані не лише на покращення морфофункціонального стану опорно-рухового апарату, але й функціонального стану організму.

3 метою покращення стану постави та підтримки рівня функціональних можливостей застосовувались вправи аеробної спрямованості, що сприяють підвищенню та підтримці рівня функціональних можливостей серцево-судинної й дихальної систем. Розроблено програму занять для студентів з використанням систем пілатесу, стретчингу та атлетичної гімнастики 3 метою підвищення рівня розвитку фізичних якостей. А.І. Альошиною (2016) запропоновано систему профілактично-оздоровчих і корекційних заходів для студентів 3 порушенням постави ${ }^{3}$.

Попри те, що порушення постави $є$ причиною зниження рівня фізичної та функціональної підготовленості у 60-65\% студентів, кількість робіт, які відображають негативний вплив порушень постави на функціонування окремих систем організму студентської молоді, обмежена ${ }^{4}$. Доведено, що постава визначає функціональні можливості організму, які зумовлюються станом внутрішніх органів і систем. Водночас сьогодні інформація щодо покращення фізичної та функціональної підготовленості студентів 3 порушенням постави шляхом використання аеробних та анаеробних навантажень висвітлена фрагментарно. Тому пошук нових ефективних підходів до вдосконалення програм занять з фізичного виховання, які передбачають не лише корекцію порушення постави, але й покращення фізичної та функціональної підготовленості студентів, зумовлює актуальність дослідження.

\section{1. Методи та організація дослідження}

Одним із основних методів дослідження був педагогічний експеримент, який проводився у вигляді констатувального та формувального. Експеримент здійснювався 3 метою виявлення у студентів порушення постави та його типу. Визначали рівень стану біогеометричного профілю

${ }^{3}$ Альошина А., Колос М. Корекція функціональних порушень опорно-рухового апарату студентів у процесі фізичного виховання. Фізичне виховання, спорт $i$ культура здоров'я у сучасному суспільстві : зб. наук. пр. Східноєвроп. нач. ун-ту ім. Лесі Українки / уклад. А.В. Цьось, С.П. Козіброцький. Луцьк : Східноєвроп. нац. унт ім. Лесі Українки, 2015. № 4(32). С. 52-56.

${ }^{4}$ Дудко М.В. Характеристика состояния биогеометрического профиля осанки и физической подготовленности студентов в процес се физического воспитания. Физическое воспитание студентов. 2015. 0;4. С. 30-35

Мартынюк О.А. Обоснование технологии мониторинга пространственной организации тела студентов в процессе физического воспитания. Фізичне виховання, спорт і культура здоров'я у сучасному суспільстві. Луцьк : Волин, нац. ун-т ім. Л. Українки, 2009. № 4(8). С. 49-53. 
постави студентів з використанням удосконаленої карти експрес-контролю біогеометричного профілю постави .

Функціональну підготовленість вивчали за показниками фізичної працездатності $\left(\mathrm{PWC}_{170}\right)$, максимального споживання кисню $\left(\mathrm{VO}_{2 \max }\right)$ за величиною максимальної кількості зовнішньої механічної роботи за 1 хв. (МКЗМР), показниками зовнішнього дихання, часом відновлення артеріального тиску та частотою серцевих скорочень після дозованих фізичних навантажень. Для цього використовувались методи велоергометрії, комп’ютерної спірографії, сфігмоманометрії та пульсометрії. Показники аеробної продуктивності організму оцінювалися за відносною величиною максимального споживання кисню з використанням критеріїв Я.П. Пярната, а рівень фізичного здоров'я - за методикою експрес-оцінки соматичного здоров'я Г.Л. Апанасенка

Формувальний педагогічний експеримент проводився 3 метою оцінки ефективності розроблених програм для студентів зі сколіотичною поставою, тривалість формувального експерименту склала один навчальний рік. Систематизація матеріалу і первинна математична обробка були виконані за допомогою таблиць Microsoft@Excel 2010.

3 огляду на особливості функціональної підготовленості студентів 3 порушенням постави нами було розроблено, теоретично обгрунтовано та впроваджено комплексний підхід до вдосконалення функціональної підготовленості студентів зі сколіотичною поставою, який включає єдність цілей, завдань, змісту, методів і форм фізичного виховання та їх взаємодії з позицій цілісності і системності.

Під час розробки комплексної програми ми дотримувались загальнометодичних принципів тренування, а саме: свідомості i активності, систематичності, послідовності, неперервності, поступовості, індивідуалізації та спеціальних принципів методики Пілатеса: концентрації, контролю м'язів, візуалізації, плавності, точності, центрування, а також принципу правильного дихання.

Факторний аналіз підготовленості юнаків та дівчат 3 порушенням постави виділив фактори, які визначили співвідношення вправ. 3 огляду на результати факторизації вивчених показників студентів зі сколіотичною поставою, розробляючи програму занять, варто дозувати вправи у співвідношенні: вправи, спрямовані на розвиток витривалості, - близько 35\%; вправи для вдосконалення анаеробних

\footnotetext{
${ }^{5}$ Пярнат Я.П. Возрастно-половые стандарты (10-50 лет) аэробной способности человека : автореф. дис.... д-ра мед. Паук : 03.00.13 / Центральный гос. ин-т. физ. к-ры. Москва, 1983, 44 с.; Апанасенко Г.Л. О возможности количественной оценки здоровья человека. Гигиена и санитария. 1985. № 6. С. 55-58.
} 
можливостей - близько $27 \%$; вправи для розвитку силової статичної витривалості м'язів спини та сідничних м'язів мають складати близько $23 \%$; а вправи, які сприятимуть вдосконаленню швидкісно-силових якостей, - близько 15\%. Результати факторизації вивчених показників студенток вказують на необхідність дозувати вправи у такому співвідношенні: спрямовані на розвиток витривалості та аеробних можливостей мають складати близько 42\%; вправи, переважно спрямовані на розвиток силової статичної витривалості м'язів спини, близько 22\%; вправи зі стимуляцією анаеробних можливостей організму - близько $21 \%$, а дихальні вправи - близько $15 \%$. Незалежно від статі для студентів з порушенням постави необхідно включати як вправи, спрямовані на зміцнення м'язів корсета, так і вправи, що покращують фізичну та функціональну підготовленість.

Отримані дані покладено в основу програми занять, яка складалася 3 чотирьох модулів: два 3 них спрямовані на розвиток аеробних можливостей у юнаків та дівчат (відповідно модуль I та II), два - на стимуляцію анаеробних можливостей організму юнаків та дівчат (відповідно модуль III та IV).

Під час розробки програми ураховувалась функціональна підготовленість студентів 3 урахуванням абсолютного значення показника VO2max, що дозволяло встановити діапазон величини енерговитрат для кожного досліджуваного (Emax).

Розроблена програма виконувалась студентами у три етапи: підготовчий, основний i підтримуючий, кожен 3 яких вирішував відповідні завдання

Незалежно від модуля студенти займались тричі на тиждень, структура кожного заняття була типовою і складалась 3 трьох частин: розминки, основної та заключної.

У вступній частині кожного заняття (під час розминки), яка тривала близько 10-12 хв, студенти виконували дихальні, загальнорозвиваючі вправи.

В основній частині заняття юнаки виконували силові вправи, а дівчата - вправи за методикою Пілатеса для підвищення тонусу постуральних м'язів. Бігова робота чергувалась 3 ходьбою, поступово зменшуючи тривалість ходьби за рахунок збільшення тривалості бігу. Запропоновані нами модулі відрізнялись за режимом енергозабезпечення бігової роботи. У модулях I та II біг в основній частині занять виконувався в аеробному режимі енергозабезпечення, а III та IV - з періодичною стимуляцією під час бігу анаеробних процесів енергозабезпечення. У заняттях за модулем I і II застосовувався метод безперервної стандартизованої вправи, а за модулями III i IV безперервної варіативної вправи. 
Контроль за інтенсивністю бігу здійснювався самостійно кожним досліджуваним за допомогою монітору серцевого ритму, за показником ЧСС, що давало змогу підтримувати заплановану інтенсивність. У процесі занять здійснювався оперативний контроль за функціональним станом студентів.

У заключній частині заняття, яка тривала 3-5 хвилин, досліджувані виконували дихальні вправи, а також вправи на розслаблення м'язів, 3 високоамплітудними рухами кінцівок.

\section{2. Результати дослідження}

Оцінка результатів впровадження запропонованої програми проводилася відповідно до критеріїв ефективності протягом всього періоду занять (32 тижнів).

У студентів КГ1 та КГ2, які займалися за типовою програмою фізичного виховання для закладів вищої освіти, не спостерігалось змін рівня стану біогеометричного профілю постави, тобто жоден зі студентів не перейшов 3 низького на середній чи 3 середнього до високого рівня стану біогеометричного профілю постави (табл. 1).

Таблиця 1

Розподіл студентів за рівнем стану біогеометричного профілю постави до та після експерименту $(\mathrm{n}=69), \%$

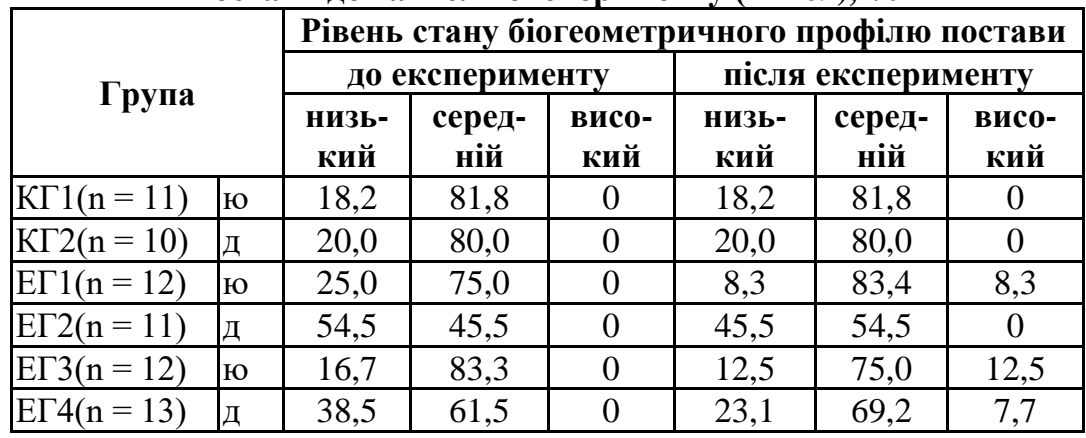

У студентів (ЕГ1) та студенток (ЕГ2) з порушенням постави, які виконували фізичне навантаження в аеробному режимі енергозабезпечення, відбулися позитивні зміни у розподілі рівня біогеометричного профілю постави. Так, у юнаків (ЕГ1) 2 студенти перейшли на середній рівень, 1 - на високий, а у дівчат (ЕГ2) 1 студентка перейшла 3 низького на середній рівень (див. табл.1).

Заняття, під час яких активно стимулювалися не лише аеробні, але й анаеробні процеси метаболізму (модулі III і IV), позитивно вплинули на 
стан біогеометричного профілю постави. Так, у групі юнаків (ЕГЗ) 1 студент перейшов на середній рівень біогеметричного профілю, 1 - на високий рівень, а у групі дівчат (ЕГ4) - 2 студентки перейшли на середній рівень і 1 студентка - на високий (див. табл. 1).

Заняття за типовою програмою не призвели до покращення стану постави за показником «ромба Мошкова»(табл. 2).

Таблиця 2

Вплив фізичних вправ за типовою програмою для закладів вищої освіти на показники постави юнаків зі сколіотичною поставою $(\mathrm{n}=22)$

\begin{tabular}{|c|c|c|c|c|c|}
\hline \multirow[b]{2}{*}{ Показник } & \multirow[b]{2}{*}{$\begin{array}{l}\text { Стать, } \\
\text { група }\end{array}$} & \multicolumn{4}{|c|}{ Середні значення, $X \pm m$} \\
\hline & & \begin{tabular}{|c|} 
до початку \\
занять \\
\end{tabular} & \begin{tabular}{|c|} 
через \\
8 тижнів \\
\end{tabular} & \begin{tabular}{|c|} 
через \\
16 тижнів \\
\end{tabular} & \begin{tabular}{|c|} 
через \\
32 тижнів \\
\end{tabular} \\
\hline $\begin{array}{l}\text { Різниця сто- } \\
\text { рін «ромба }\end{array}$ & & $1,2 \pm 0,03$ & & $1,16 \pm 0,04$ & $1,13 \pm 0,04$ \\
\hline $\begin{array}{l}\text { Мошкова», } \\
\text { см }\end{array}$ & $\begin{array}{c}\text { д, КГ2 } \\
(\mathrm{n}=10)\end{array}$ & $1,59 \pm 0,05$ & $1,54 \pm 0,05$ & $1,49 \pm 0,05$ & $1,48 \pm 0,05$ \\
\hline
\end{tabular}

Примітка: вірогідність відмінності показників відсутня

Після впровадження у процес фізичного виховання студентів занять за аеробним модулем нами були зареєстровані позитивні зміни стану постави. Як у юнаків (ЕГ1), так і у дівчат (ЕГ2) покращились показники різниці сторін «ромба Мошкова» через 16 тижнів від початку занять відповідно на $2,5 \%(\mathrm{p}<0,05)$ та $2,3 \%$, а через 32 тижні відповідно на $3,0 \%$ та $2,4 \%(\mathrm{p}<0,05)$ (табл. 3).

Таблиця 3

Вплив фізичних вправ за аеробним модулем на показники постави студентів зі сколіотичною поставою $(\mathbf{n}=23)$

\begin{tabular}{|c|c|c|c|c|c|}
\hline \multirow[b]{2}{*}{ Показник } & \multirow[b]{2}{*}{$\begin{array}{l}\text { Стать, } \\
\text { група }\end{array}$} & \multicolumn{4}{|c|}{ Середні значення, $\mathrm{X} \pm m$} \\
\hline & & $\begin{array}{c}\text { до початку } \\
\text { занять }\end{array}$ & $\begin{array}{c}\text { через } \\
8 \text { тижнів }\end{array}$ & $\begin{array}{c}\text { через } \\
16 \text { тижнів }\end{array}$ & $\begin{array}{c}\text { через } \\
32 \text { тижнів }\end{array}$ \\
\hline $\begin{array}{l}\text { Різниця сто- } \\
\text { рін «ромба }\end{array}$ & $\begin{array}{l}\text { ю, EГ1 } \\
(\mathrm{n}=12)\end{array}$ & $1,2 \pm 0,03$ & $1,19 \pm 0,03$ & $1,16 \pm 0,04 *$ & $1,13 \pm 0,04^{*}$ \\
\hline $\begin{array}{l}\text { Мошкова», } \\
\text { см }\end{array}$ & $\begin{array}{c}\text { д, ЕГ2 } \\
(\mathrm{n}=11)\end{array}$ & $1,59 \pm 0,05$ & $1,54 \pm 0,05$ & $1,49 \pm 0,05 *$ & $1,48 \pm 0,05^{*}$ \\
\hline
\end{tabular}

Примітка: вірогідність відмінності показника відносно вихідних даних: * $\mathrm{P}<0,05$ 
У студентів, які займались за анаеробним модулем, також спостерігалось вірогідне зменшення асиметрії у фронтальній площині, про що свідчить зниження показника різниці сторін «ромба Мошкова» (табл. 4).

Таблиця 4

Вплив фізичних вправ за анаеробним модулем на показники постави юнаків зі сколіотичною поставою (n=25)

\begin{tabular}{|c|c|c|c|c|c|}
\hline \multirow[b]{2}{*}{ Показник } & \multirow{2}{*}{$\begin{array}{l}\text { Стать, } \\
\text { група }\end{array}$} & \multicolumn{4}{|c|}{ Середні значення, $\mathrm{X} \pm \mathrm{m}$} \\
\hline & & $\begin{array}{c}\text { до початку } \\
\text { занять }\end{array}$ & $\begin{array}{c}\text { через } \\
8 \text { тижнів }\end{array}$ & $\begin{array}{c}\text { через } \\
16 \text { тижнів }\end{array}$ & $\begin{array}{c}\text { через } \\
32 \text { тижнів }\end{array}$ \\
\hline $\begin{array}{l}\text { Різниця сторін } \\
\text { «ромба Мош- } \\
\text { кова», см }\end{array}$ & $\begin{array}{c}\text { ю, Г1 } \\
(\mathrm{n}=12)\end{array}$ & $1,23 \pm 0,04$ & $1,2 \pm 0,05$ & $1,18 \pm 0,04^{*}$ & $1,17 \pm 0,04 *$ \\
\hline $\begin{array}{l}\text { Різниця сторін } \\
\text { «ромба Мош- } \\
\text { кова», см }\end{array}$ & $\begin{array}{c}\text { д, ЕГ2 } \\
(\mathrm{n}=13)\end{array}$ & $1,47 \pm 0,05$ & $1,45 \pm 0,05$ & $1,4 \pm 0,05^{*}$ & $1,37 \pm 0,04 *$ \\
\hline
\end{tabular}

Примітка: вірогідність відмінності показника відносно вихідних даних: *$\mathrm{P}<0,05$

Так, у юнаків (ЕГЗ) через 16 тижнів після початку занять середні величини вірогідно зменшились на $2,1 \%(\mathrm{p}<0,05)$, а через 32 тижні на $2,4 \%(\mathrm{p}<0,05)$. У дівчат $(\mathrm{EГ} 4)$ середні значення показника різниці «ромба Мошкова» зросли через 16 тижнів на 2,0\% $(\mathrm{p}<0,05)$, а через 32 тижні - на 2,1\%(p <0,05).

Отже, під час проведення дослідження нами було встановлено позитивний вплив фізичних вправ за розробленою програмою, який проявився в кількісному підвищенні рівні стану біогеометричного профілю постави та зменшенні асиметрії.

Як видно 3 таблиці 5, заняття за цією програмою не викликали вірогідних змін абсолютних і відносних показників фізичної працездатності, аеробної та анаеробної (лактатної) продуктивності.

За програмою занять закладів вищої освіти у юнаків з порушенням постави, вихідний рівень аеробної продуктивності яких за відносною величиною $\mathrm{Vo}_{2}$ max відповідав «низькому». У студентів, які займались за програмою закладів вищої освіти, не зареєстровано підвищення РАП за відносною величиною максимального споживання кисню.

Заняття за цією програмою не викликали вірогідного зростання середніх величин відносних показників $\mathrm{PWC}_{170}$ та $\mathrm{Vo}_{2}$ max. (табл. 6). 
Таблиця 5

Вплив занять за програмою закладів вищої освіти на аеробну та анаеробну (лактатну) продуктивність юнаків 3 порушенням постави $(\mathrm{n}=12)$

\begin{tabular}{|c|c|c|c|c|}
\hline \multirow[b]{2}{*}{ Показники } & \multicolumn{4}{|c|}{ Середня величина $(\mathrm{X} \pm \mathrm{m})$} \\
\hline & $\begin{array}{c}\text { до початку } \\
\text { занять }\end{array}$ & $\begin{array}{c}\text { через } \\
8 \text { тижнів }\end{array}$ & $\begin{array}{c}\text { через } \\
16 \text { тижнів }\end{array}$ & $\begin{array}{c}\text { через } \\
32 \text { тижнів }\end{array}$ \\
\hline $\begin{array}{l}\mathrm{PWC}_{170} \\
\text { кгм Хв }\end{array}$ & $787,18 \pm 23,47$ & $809,88 \pm 23,03$ & $809,77 \pm 24,77$ & $809,29 \pm 25,59$ \\
\hline $\begin{array}{l}\mathrm{PWC}_{170} \\
\mathrm{~K}^{-1} \cdot \mathrm{XB}^{-1} \cdot \mathrm{K}^{-1}\end{array}$ & $10,32 \pm 0,19$ & $10,72 \pm 0,2$ & $11,01 \pm 0,24$ & $11,01 \pm 0,24$ \\
\hline $\begin{array}{l}\mathrm{VO}_{2 \max }, \\
\mathrm{MI} \mathrm{XB}^{-1}\end{array}$ & $2576,7 \pm 41,09$ & $2616,96 \pm 39,23$ & $2617,6 \pm 42,11$ & $2613,78 \pm 39,33$ \\
\hline 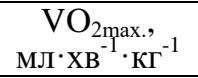 & $33,93 \pm 0,4$ & $34,77 \pm 0,46$ & $35,15 \pm 0,49$ & $35,14 \pm 0,53$ \\
\hline $\begin{array}{l}\text { МКЗМР, } \\
\text { кгм хв }\end{array}$ & $1218,71 \pm 54,14$ & $1287,45 \pm 48,4$ & $1340,09 \pm 48,4$ & $1353,14 \pm 48,4$ \\
\hline $\begin{array}{c}\text { МКЗМР, } \\
\mathrm{KгM}^{*} \cdot \mathrm{XB}^{-1} \cdot \mathrm{K}^{-1}\end{array}$ & $16,11 \pm 0,78$ & $17,11 \pm 0,78$ & $17,88 \pm 0,8$ & $18,07 \pm 0,83$ \\
\hline Маса тіла, кг & $76,17 \pm 1,85$ & $75,67 \pm 1,95$ & $75,5 \pm 1,85$ & $75,33 \pm 1,85$ \\
\hline
\end{tabular}

Примітка: вірогідність відмінності показника відносно вихідних даних: * $\mathrm{P}<0,05 ; * *-\mathrm{P}<0,01$

Таблиця 6

Вплив занять за програмою закладів вищої освіти на аеробну та анаеробну (лактатну) продуктивність дівчат з порушенням ( $\mathrm{n}=11)$

\begin{tabular}{|c|c|c|c|c|}
\hline \multirow[b]{2}{*}{ Показники } & \multicolumn{4}{|c|}{ Середня величина ( $\mathrm{X} \pm m)$} \\
\hline & $\begin{array}{c}\text { до початку } \\
\text { занять }\end{array}$ & $\begin{array}{c}\text { через } \\
8 \text { тижнів }\end{array}$ & \begin{tabular}{c|} 
через \\
16 тижнів \\
\end{tabular} & $\begin{array}{c}\text { через } \\
32 \text { тижнів }\end{array}$ \\
\hline $\begin{array}{l}\text { PWC }_{170}, \\
\text { кГм Хв }\end{array}$ & $645,75 \pm 28,5$ & $650,4 \pm 15,3$ & $670,53 \pm 25,27$ & $697,72 \pm 23,09$ \\
\hline $\begin{array}{l}\mathrm{PWC}_{170,}, \\
\text { Кгм } \mathrm{XB}^{-1} \cdot \mathrm{K \Gamma}^{-1}\end{array}$ & $10,85 \pm 0,24$ & $11,05 \pm 0,23$ & $11,56 \pm 0,26$ & $12,08 \pm 0,23^{* *}$ \\
\hline $\begin{array}{l}\mathrm{VO}_{2 \max }, \\
\mathrm{M} \cdot \mathrm{XB}^{-1}\end{array}$ & $2337,82 \pm 48,45$ & $2345,22 \pm 31,11$ & $2379,31 \pm 42,95$ & $2425,97 \pm 45,24$ \\
\hline 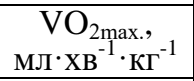 & $39,47 \pm 0,81$ & $40,01 \pm 0,81$ & $40,78 \pm 0,7$ & $42,17 \pm 0,88^{*}$ \\
\hline $\begin{array}{l}\text { МКЗМР, } \\
\text { Кгм Хв }\end{array}$ & $1129,67 \pm 48,77$ & $1151,35 \pm 46.39$ & $1187,28 \pm 44.84$ & $1250,98 \pm 44,18$ \\
\hline $\begin{array}{l}\text { MКЗМР, } \\
\text { КгМ } \cdot \mathrm{XB}^{-1} \cdot \mathrm{K}^{-1}\end{array}$ & $19,12 \pm 0,99$ & $19,71 \pm 1,11$ & $20,58 \pm 1,15$ & $21,81 \pm 1,12$ \\
\hline Маса тіла, кг & $59,45 \pm 1,7$ & $58,82 \pm 1,39$ & $58 \pm 1,4$ & $57,73 \pm 1,4$ \\
\hline
\end{tabular}

Примітка: вірогідність відмінності показника відносно вихідних даних: ** $\mathrm{P}<0,01 ; * * *-\mathrm{P}<0,001$ 
У дівчат з порушенням постави РАП до початку занять оцінювався в середньому як «відмінний». Слід відзначити, що на всіх етапах дослідження відносна величина $\mathrm{VO}_{2 \text { max }}$ дівчат відповідала «відмінному» (за Г.Л. Апанасенком), залишаючись такою до завершення 32-х тижневого тренувального циклу. ${ }^{6}$

За модулем I тренувалося 12 юнаків 3 порушенням постави, вихідний рівень аеробної продуктивності яких за відносною величиною $\mathrm{VOo}_{2}$ mах відповідав «низькому».

Як видно 3 таблиці 7, заняття за цим модулем протягом 8 тижнів не викликали вірогідних змін абсолютних і відносних показників фізичної працездатності, аеробної та анаеробної (лактатної) продуктивності.

Таблиця 7

Вплив занять в аеробному режимі енергозабезпечення (за модулем I) на аеробну та анаеробну (лактатну) продуктивність юнаків 3 порушенням постави $(\mathrm{n}=12)$

\begin{tabular}{|c|c|c|c|c|}
\hline \multirow[b]{2}{*}{ Показники } & \multicolumn{4}{|c|}{ Середня величина $(\mathrm{X} \pm \mathrm{m})$} \\
\hline & $\begin{array}{c}\text { до початку } \\
\text { занять }\end{array}$ & $\begin{array}{c}\text { через } \\
8 \text { тижнів }\end{array}$ & $\begin{array}{c}\text { через } \\
16 \text { тижнів }\end{array}$ & $\begin{array}{c}\text { через } \\
32 \text { тижнів }\end{array}$ \\
\hline & $833,06 \pm 23,42$ & $853,2 \pm 24,01$ & $887,42 \pm 26,36$ & $902,83 \pm 25,59$ \\
\hline $\begin{array}{r}\mathrm{PW} \\
\text { кгм } \cdot \mathrm{x}\end{array}$ & $10,93 \pm 0,18$ & $11,25 \pm 017$ & $11,74 \pm 0,17 *$ & $11,95 \pm 0,15^{* *}$ \\
\hline & $2656,19 \pm 39,82$ & $2690,43 \pm 40,82$ & $2748,62 \pm 44,8$ & $2779,05 \pm 47,75$ \\
\hline 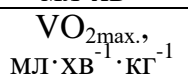 & $34,98 \pm 0,4$ & $35,62 \pm 0,44$ & $36,51 \pm 0,47^{*}$ & $36,94 \pm 0,44^{*}$ \\
\hline $\begin{array}{l}\text { МКЗМР, } \\
\text { Кгм хв }{ }^{-1}\end{array}$ & $1218,71 \pm 54,14$ & $1287,45 \pm 48,4$ & $1340,09 \pm 48,4$ & $1353,14 \pm 48,4$ \\
\hline $\begin{array}{l}\text { МКЗМР, } \\
\text { КгМ } \cdot \mathrm{XB}^{-1} \cdot \mathrm{K}^{-1}\end{array}$ & $16,11 \pm 0,78$ & $17,11 \pm 0,78$ & & $18,07 \pm 0,83$ \\
\hline Иаса тіла, & $76,17 \pm 1,85$ & $75,67 \pm 1,95$ & $75,5 \pm 1,85$ & $75,33 \pm 1,85$ \\
\hline
\end{tabular}

Примітка: вірогідність відмінності показника відносно вихідних даних: * $\mathrm{P}<0,05 ; * *-\mathrm{P}<0,01$

Через 16 тижнів середня величина відносного показника $\mathrm{PWC}_{170}$ зросла на $7,41 \%(\mathrm{p}<0,05)$, а через 32 тижні - на 9,34\% (p < 0,01). Середнє значення відносного показника $\mathrm{Vo}_{2}$ max через 16 тижнів від початку занять збільшилась на $4,38 \%$ ( $<<0,01)$, а через 32 тижнів зросла на 5,61\% (рис 1, 2 ). Водночас абсолютні показники $\mathrm{PWC}_{170}$

${ }^{6}$ Апанасенко Г.Л. О возможности количественной оценки здоровья человека. Гигиена и санитария. 1985. № 6. С. 55-58. 
i $\mathrm{Vo}_{2}$ max вірогідно не змінились протягом 32 тижневого циклу тренувань, а відносні показники МКЗМР, які характеризують анаеробні (лактатні) процеси, енергозабезпечення, за весь період занять (32 тижні) залишилися без істотних змін (див. табл. 8).

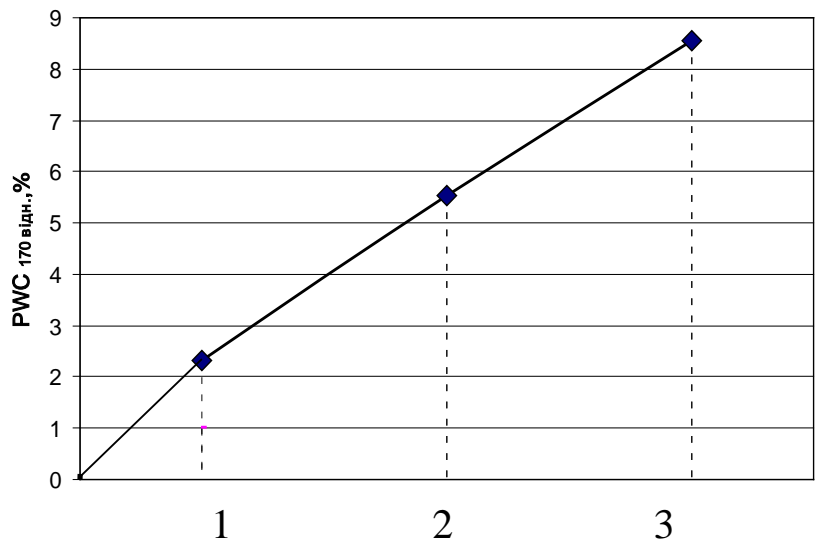

Рис. 1. Динаміка змін середньої величини $\mathrm{PWC}_{170 \text { відн. }}$ під впливом занять за модулем I у юнаків, у \% відносно вихідного рівня: 1 - через 8 тижнів від початку занять; 2- через 16 тижнів від початку занять; 3 - через 32 тижні від початку занять

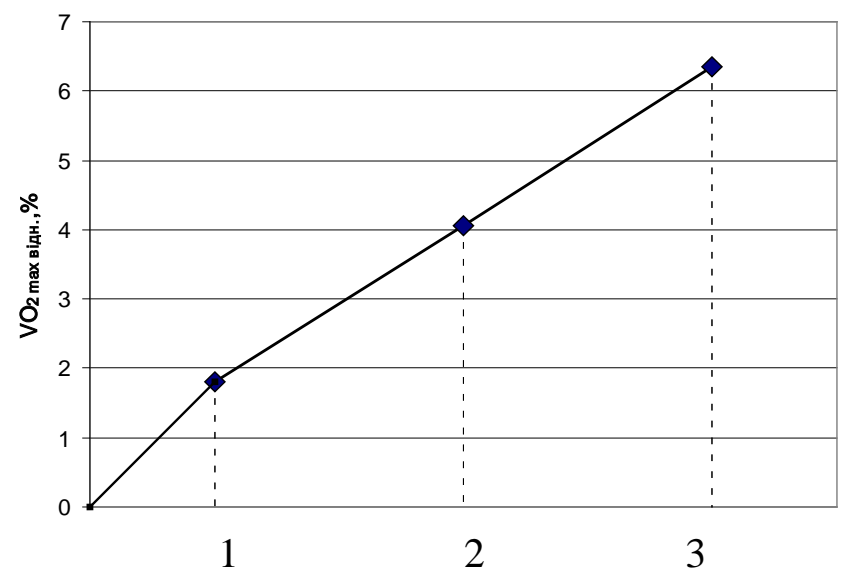

Рис. 2. Динаміка змін середньої величини VO2 під впливом занять за модулем I у юнаків, у \% відносно вихідного рівня: 1 - через 8 тижнів від початку занять; 2 - через 16 тижнів від початку занять; 3 - через 32 тижні від початку занять 
Середня величина маси тіла юнаків протягом зазначеного періоду занять вірогідно не змінилася. У студентів першої групи, які виконували навантаження за модулем I, не зареєстровано підвищення РАП за відносною величиною максимального споживання кисню.

У дівчат з порушенням постави, які займалися за модулем II, РАП до початку занять оцінювався в середньому як «відмінний». Слід відзначити, що на всіх етапах дослідження відносна величина $\mathrm{Vo}_{2 \max }$ дівчат перевищувала «критичний» рівень здоров'я, залишаючись таким до завершення 32 тижневого тренувального циклу. Заняття за цим модулем також викликали вірогідне зростання середніх величин

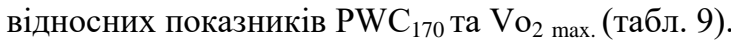

Таблиця 9

Вплив занять в аеробному режимі енергозабезпечення (за модулем II) на аеробну та анаеробну (лактатну) продуктивність дівчат 3 порушенням ( $n=11)$

\begin{tabular}{|c|c|c|c|c|}
\hline \multirow[b]{2}{*}{ Показники } & \multicolumn{4}{|c|}{ Середня величина ( $\mathrm{X} \pm m)$} \\
\hline & $\begin{array}{c}\text { до початку } \\
\text { занять }\end{array}$ & $\begin{array}{c}\text { через } \\
8 \text { тижнів }\end{array}$ & $\begin{array}{c}\text { через } \\
16 \text { тижнів }\end{array}$ & $\begin{array}{c}\text { через } \\
32 \text { тижнів }\end{array}$ \\
\hline $\begin{array}{l}\mathrm{PWC}_{170}, \\
\text { кгм Хв }\end{array}$ & $645,75 \pm 28,5$ & $650,4 \pm 15,3$ & $670,53 \pm 25,27$ & $697,72 \pm 23,09$ \\
\hline $\begin{array}{l}\mathrm{PWC}_{170}, \\
\mathrm{~K}^{-1} \cdot \mathrm{XB}^{-1} \cdot \mathrm{K}^{-1}\end{array}$ & $10,85 \pm 0,24$ & $11,05 \pm 0,23$ & $11,56 \pm 0,26$ & $12,08 \pm 0,23^{* *}$ \\
\hline $\begin{array}{l}\mathrm{VO}_{2 \max }, \\
\mathrm{M} \cdot \mathrm{XB}^{-1}\end{array}$ & $2337,82 \pm 48,45$ & $2345,22 \pm 31,11$ & $2379,31 \pm 42,95$ & $2425,97 \pm 45,24$ \\
\hline $\begin{array}{c}\mathrm{VO}_{2 \text { max., }} \\
\mathrm{M}^{-} \cdot \mathrm{XB}^{-1} \cdot \mathrm{K \Gamma}^{-1}\end{array}$ & $39,47 \pm 0,81$ & $40,01 \pm 0,81$ & $40,78 \pm 0,7$ & $42,17 \pm 0,88 *$ \\
\hline $\begin{array}{l}\text { МКЗМР, } \\
\text { кгм хв }\end{array}$ & $1129,67 \pm 48,77$ & $1151,35 \pm 46.39$ & $1187,28 \pm 44.84$ & $1250,98 \pm 44,18$ \\
\hline 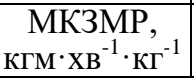 & $19,12 \pm 0,99$ & $19,71 \pm 1,11$ & $20,58 \pm 1,15$ & $21,81 \pm 1,12$ \\
\hline Маса тіла, кг & $59,45 \pm 1,7$ & $58,82 \pm 1,39$ & $58 \pm 1,4$ & $57,73 \pm 1,4$ \\
\hline
\end{tabular}

Примітка: вірогідність відмінності показника відносно вихідних даних: ** $\mathrm{P}<0,01 ; * * *-\mathrm{P}<0,001$

Через 28 тижнів від початку занять у досліджуваних, які займалися за модулем II, середні величини відносних показників $\mathrm{PWC}_{170} \mathrm{Ta} \mathrm{Vo}_{2}$ max зросли відповідно на $11,34 \%(\mathrm{P}<0,01)$ та на $6,84 \%(\mathrm{P}<0,05)$ відносно вихідного рівня (рис. 3, 4).

У дівчат, які виконували навантаження в аеробному режимі, енергозабезпечення не відбулося суттєвих змін абсолютної та відносної величин МКЗМР. 


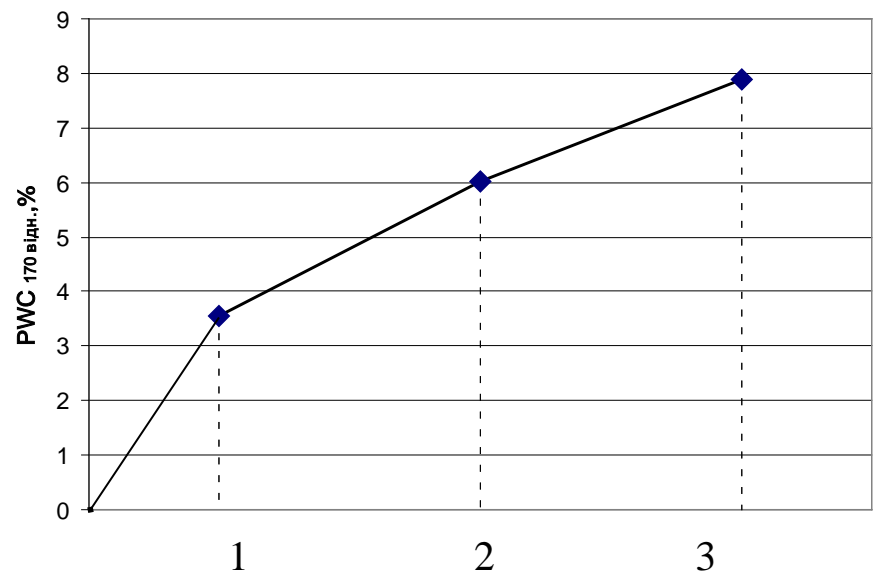

Рис. 3. Динаміка змін середньої величини $\mathrm{PWC}_{170 \text { відн. }}$ під впливом занять за модулем ІІ у дівчат, у \% відносно вихідного рівня: 1 - через 8 тижнів від початку занять; 2 - через 16 тижнів від початку занять; 3 - через 32 тижні від початку занять

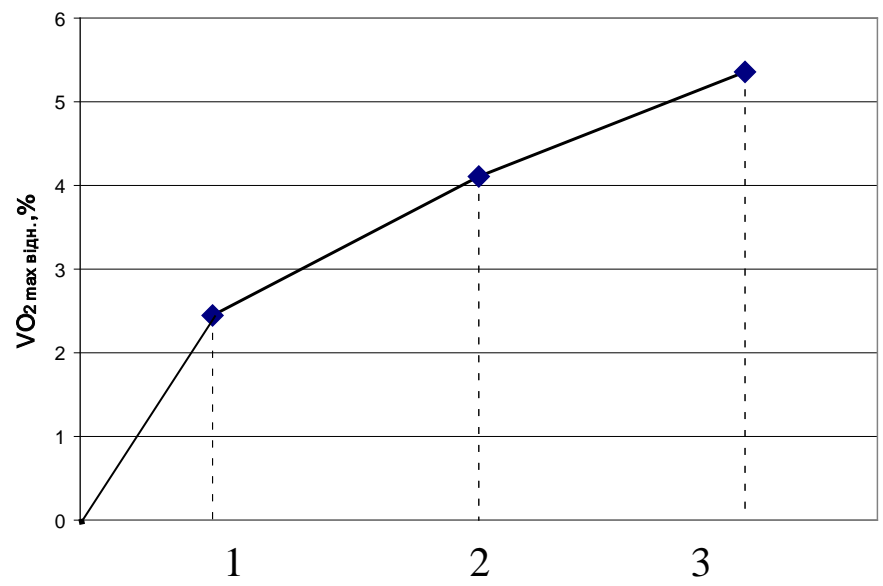

Рис. 4. Динаміка змін середньої величини VO2 тах відн. під впливом занять за модулем ІІ у дівчат, у \% відносно вихідного рівня: 1 - через 8 тижнів від початку занять; 2 - через 16 тижнів від початку занять; 3 - через 32 тижні від початку занять

Протягом 32 тижнів тренувань середній показник маси тіла дівчат вірогідно не змінився. 
За модулем III (зі стимуляцією анаеробних процесів енергозабезпечення) займалося 12 студентів чоловічої статі 3 порушенням постави. Рівень аеробної продуктивності за величиною $\mathrm{Vo}_{2}$ max студентів цісї групи у середньому виявився «низьким». Заняття за вказаним модулем викликали вірогідне зростання функціональної підготовленості студентів 3 порушенням постави за абсолютними i відносними показниками $\mathrm{PWC}_{170} \mathrm{Ta} \mathrm{Vo}_{2}$ max (табл.10).

Таблиця 10

Вплив занять в анаеробному режимі енергозабезпечення (за модулем III) на аеробну та анаеробну продуктивність юнаків 3 порушенням постави $(\mathbf{n}=12)$

\begin{tabular}{|c|c|c|c|c|}
\hline \multirow[b]{2}{*}{ Показники } & \multicolumn{4}{|c|}{ Середня величина $(\mathrm{X} \pm m)$} \\
\hline & $\begin{array}{c}\text { до початку } \\
\text { занять }\end{array}$ & $\begin{array}{c}\text { Через } \\
8 \text { тижнів }\end{array}$ & $\begin{array}{c}\text { через } \\
16 \text { тижнів }\end{array}$ & $\begin{array}{c}\text { через } \\
32 \text { тижнів } \\
\end{array}$ \\
\hline $\begin{array}{l}\mathrm{PWC}_{170}, \\
\text { кгм Хв }\end{array}$ & $\begin{array}{r}845,26 \\
\pm 24,59 \\
\end{array}$ & $\begin{array}{l}973,83 \\
\pm 47,46\end{array}$ & $\begin{array}{c}991,2 \\
\pm 45,23^{* *}\end{array}$ & $\begin{array}{c}1034,48 \\
\pm 45,37 * * *\end{array}$ \\
\hline $\begin{array}{c}\mathrm{PWC}_{170}, \\
\mathrm{\kappa} \mathrm{M}^{-1} \mathrm{XB}^{-1} . \mathrm{K}^{-1}\end{array}$ & $\begin{array}{l}10,98 \\
\pm 0,13 \\
\end{array}$ & $\begin{array}{c}12,72 \\
\pm 0,42 * * \\
\end{array}$ & $\begin{array}{c}13,0 \\
\pm 0,38^{* * *} \\
\end{array}$ & $\begin{array}{c}13,6 \\
\pm 0,47^{* * *} \\
\end{array}$ \\
\hline $\begin{array}{l}\mathrm{VO}_{2 \text { max }}, \\
\mathrm{M} \cdot \mathrm{XB}^{-1}\end{array}$ & $\begin{array}{c}2676,93 \\
\pm 41,8 \\
\end{array}$ & $\begin{array}{c}2895,51 \\
\pm 80,68 \\
\end{array}$ & $\begin{array}{l}2925,04 \\
\pm 76,9 * *\end{array}$ & $\begin{array}{c}2998,61 \\
\pm 90,46^{* *}\end{array}$ \\
\hline 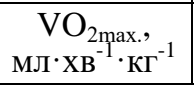 & $\begin{array}{c}34,98 \\
\pm 0,7\end{array}$ & $\begin{array}{c}38,03 \\
\pm 0,65 *\end{array}$ & $\begin{array}{c}38,6 \\
\pm 0,59 * * *\end{array}$ & $\begin{array}{c}39,66 \\
\pm 0,78^{* * *}\end{array}$ \\
\hline $\begin{array}{l}\text { МКЗМР, } \\
\text { кгм хв }{ }^{-1}\end{array}$ & $\begin{array}{c}1262,61 \\
\pm 55,49 \\
\end{array}$ & $\begin{array}{c}1323,97 \\
\pm 47,77 \\
\end{array}$ & $\begin{array}{l}1482,88 \\
\pm 62,35 * \\
\end{array}$ & $\begin{array}{c}1584,29 \\
\pm 47,08^{* * *} \\
\end{array}$ \\
\hline 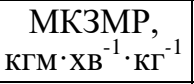 & $\begin{array}{l}16,47 \\
\pm 1,22 \\
\end{array}$ & $\begin{array}{l}17,43 \\
\pm 1,63 \\
\end{array}$ & $\begin{array}{c}19,68 \\
\pm 0,94^{*} \\
\end{array}$ & $\begin{array}{c}21,05 \\
\pm 0,92 * * *\end{array}$ \\
\hline Маса тіла, кг & $\begin{array}{c}77,08 \\
\pm 2,5\end{array}$ & $\begin{array}{l}76,33 \\
\pm 2,32\end{array}$ & $\begin{array}{c}76 \\
\pm 2,41\end{array}$ & $\begin{array}{l}75,83 \\
\pm 2,32\end{array}$ \\
\hline
\end{tabular}

Примітка: вірогідність відмінності показника відносно вихідних даних: * $\mathrm{P}<0,05 ; * *-\mathrm{P}<0,01 ; * * *-\mathrm{P}<0,001$

Через 8 тижнів від початку занять вірогідно зросли відносні показники $\mathrm{PWC}_{170}$ та $\mathrm{Vo}_{2}$ max. Середня величина $\mathrm{PWC}_{170}$ відн. за цей період занять зросла на 10,79\% (p<0,01), а Vo2 тах відн. на 7,08\% (p<0,05), тоді як абсолютні показники $\mathrm{PWC}_{170}$ та $\mathrm{Vo}_{2}$ max не змінились. Через 16 тижнів занять вірогідно покращилися абсолютні та відносні показники $\mathrm{PWC}_{170}$ та $\mathrm{Vo}_{2}$ max. Середні величини показника $\mathrm{PWC}_{170 \text { абс }}$ збільшились відносно вихідного рівня на $24.71 \%(\mathrm{p}<0,05), \mathrm{Vo}_{2}$ max абс на $12,76 \%(\mathrm{p}<0,01), \mathrm{PWC}_{170 \text { відн. }}$ на $26,24 \%(\mathrm{p}<0,001)$ та $\mathrm{Vo}_{2}$ maх відн. На $16,02 \%(\mathrm{p}<0,001)$ (рис. 5,6$)$. 


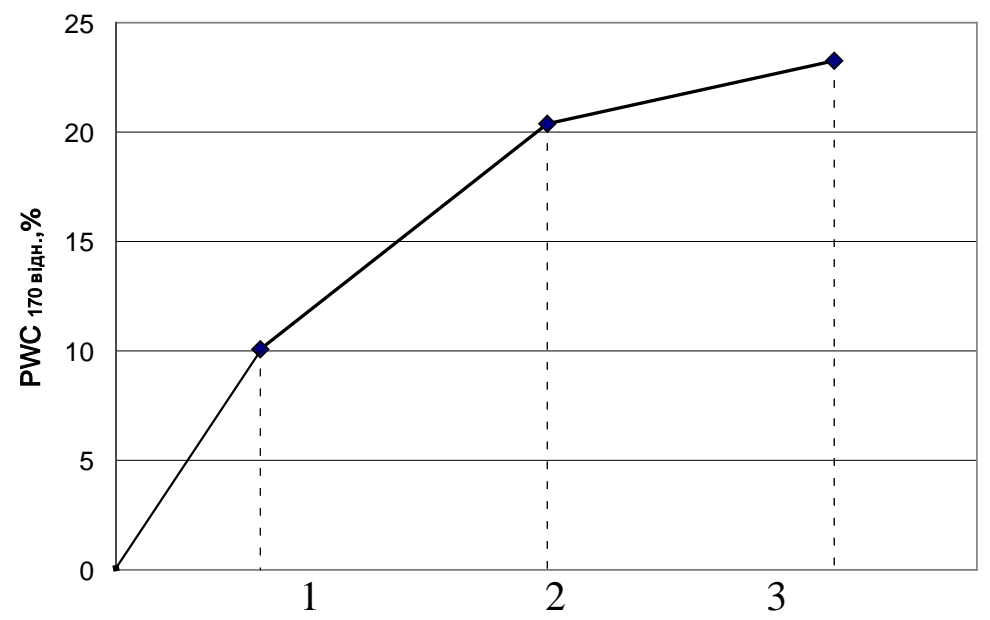

Рис. 5. Динаміка змін середньої величини $\mathrm{PWC}_{170 \text { відн. }}$ під впливом занять за модулем ІІІ у юнаків, у \% відносно вихідного рівня: 1 - через 8 тижнів від початку занять; 2 - через 16 тижнів від початку занять; 3 - через 32 тижні від початку занять

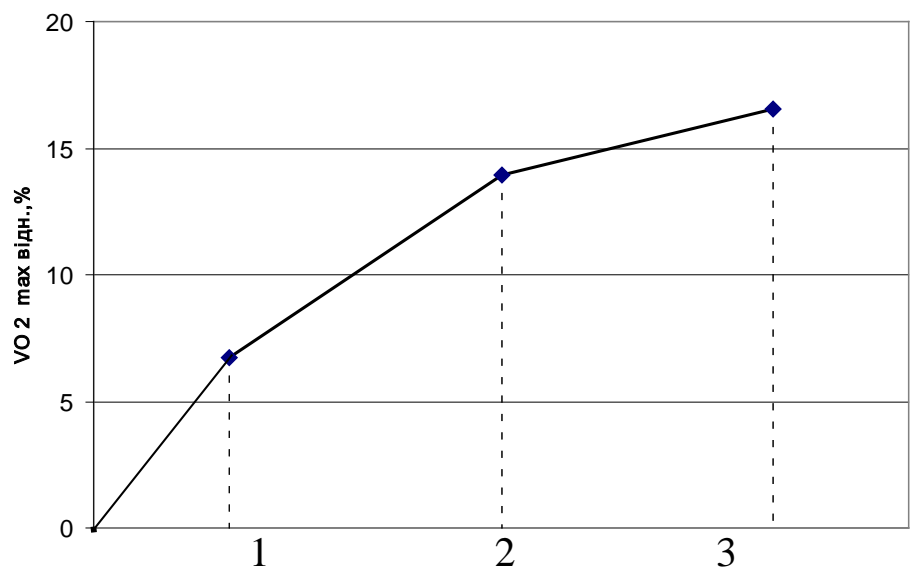

Рис. 6. Динаміка змін середньої величини VO2 тах відн. під впливом занять за модулем ІІІ у юнаків, у \% відносно вихідного рівня: 1 - через 8 тижнів від початку занять; 2 - через 16 тижнів від початку занять; 3 - через 32 тижні від початку занять

Середня величина МКЗМР абс. за цей період занять зросла на $17,45 \%$ $(\mathrm{P}<0,05)$, а МКЗМР відн. на $19,49 \%(\mathrm{P}<0,05)$ відносно вихідного рівня. 
Через 32 тижнів занять середні величини абсолютних та відносних показників $\mathrm{PWC}_{170}$ та $\mathrm{Vo}_{2}$ max досягли максимуму. Зокрема, показник $\mathrm{PWC}_{170}$ абс збільшився відносно вихідного рівня на $27,97 \%(\mathrm{p}<0,01)$,

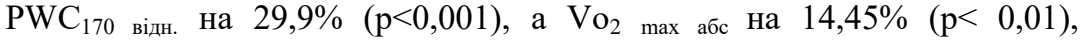
$\mathrm{Vo}_{2}$ max відн. на $18 \%(\mathrm{p}<0,001)$.

По завершенню 32-х тижневого циклу занять середня величина показника МКЗМР абс. збільшилася відносно вихідного рівня на 25,32\% (Р $<0,001)$, а МКЗМР відн на 27,81\% (P $<0,001)($ див. рис. 6 та 7).

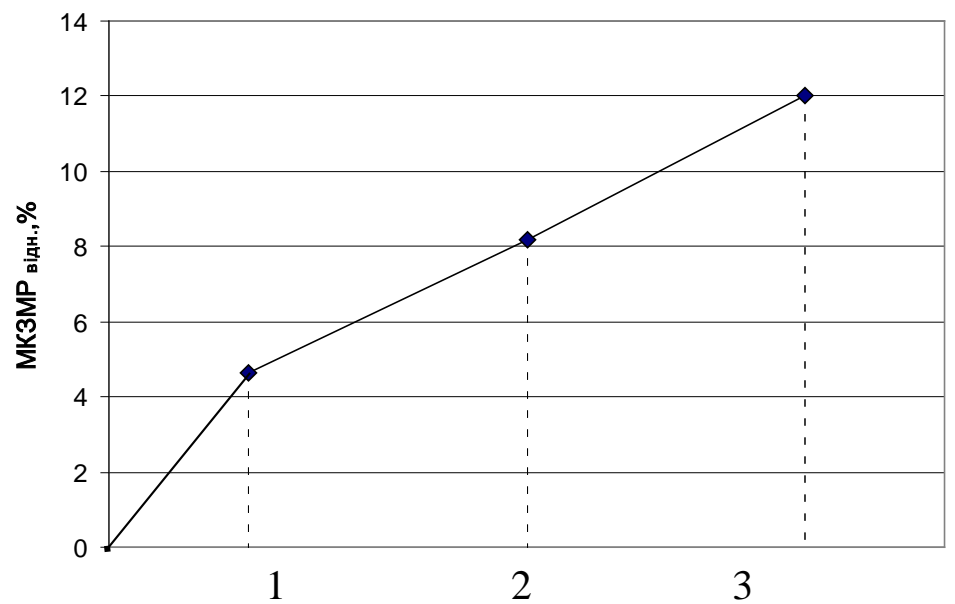

Рис. 7. Динаміка змін середньої величини МКЗМР відн. під впливом занять за модулем III у юнаків, у \% відносно вихідного рівня:

1 - через 8 тижнів від початку занять; 2 - через 16 тижнів від початку занять; 3 - через 32 тижні від початку занять

Рівень аеробної продуктивності через 16 тижнів від початку занять покращився 3 «низького» до «нижче посереднього» і залишався на цьому рівні до завершення періоду занять. Середня величина маси тіла юнаків протягом всього періоду занять вірогідно не змінилась. Такі зміни свідчать про високу ефективність запропонованої програми.

Заняття за модулем IV достатньо ефективно вплинули на функціональну підготовленість студентів (табл. 11).

У студенток з порушенням постави, які займалися за модулем IV, рівень аеробної продуктивності до початку і по завершенню занять знаходився на рівні «відмінного». Так, середня величина відносного показника $\mathrm{PWC}_{170 \text { відн. }}$ за 8 тижнів вірогідно зросла на $6,43 \%(\mathrm{p}<0,05)$. Через 16 тижнів від початку занять зросли відносні показники $\mathrm{PWC}_{170}$ на $15,19 \%(\mathrm{P}<0,001)$ та $\mathrm{Vo}_{2}$ max на $8,42 \%(\mathrm{P}<0,001)$ відносно вихідного 
рівня (рис. 8, 9). Через 32 тижнів занять середні величини абсолютних

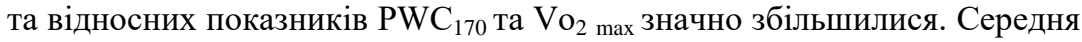
величина абсолютного показника $\mathrm{PWC}_{170}$ за цей період занять зросла на $20 \%(\mathrm{P}<0,01), \mathrm{Vo}_{2}$ max $\mathrm{Ha} 9,61 \%(\mathrm{P}<0,01)$.

Таблиця 11

Вплив занять в анаеробному режимі енергозабезпечення (за модулем IV) на аеробну та анаеробну (лактатну) продуктивність дівчат 3 порушенням постави $(n=13)$

\begin{tabular}{|c|c|c|c|c|}
\hline \multirow[b]{2}{*}{ Показники } & \multicolumn{4}{|c|}{ Середня величина, $\mathrm{X} \pm m$} \\
\hline & $\begin{array}{c}\text { до початку } \\
\text { занять }\end{array}$ & $\begin{array}{c}\text { через } \\
8 \text { тижнів }\end{array}$ & $\begin{array}{c}\text { через } \\
16 \text { тижнів }\end{array}$ & $\begin{array}{c}\text { через } \\
32 \text { тижнів }\end{array}$ \\
\hline $\begin{array}{l}\mathrm{PWC}_{170}, \\
\text { кГм Хв }\end{array}$ & $\begin{array}{c}674,1 \\
\pm 30,74\end{array}$ & $\begin{array}{l}707,29 \\
\pm 32,99\end{array}$ & $\begin{array}{r}760,37 \\
\pm 34,55\end{array}$ & $\begin{array}{l}808,95 \\
\pm 35^{* *}\end{array}$ \\
\hline 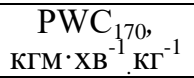 & $\begin{array}{l}10,73 \\
\pm 0,15 \\
\end{array}$ & $\begin{array}{c}11,42 \\
\pm 0,14 * *\end{array}$ & $\begin{array}{c}12,36 \\
\pm 0,14 * * *\end{array}$ & $\begin{array}{c}13,23 \\
\pm 0,16^{* * *}\end{array}$ \\
\hline $\begin{array}{l}\mathrm{VO}_{2 \text { max }}, \\
\text { мЛ } \mathbf{X B}^{-1}\end{array}$ & $\begin{array}{c}2385,98 \\
\pm 52,25 \\
\end{array}$ & $\begin{array}{l}2442,4 \\
\pm 56,07\end{array}$ & $\begin{array}{c}2532,63 \\
\pm 58,73 \\
\end{array}$ & $\begin{array}{l}2615,21 \\
\pm 59,5 * *\end{array}$ \\
\hline $\begin{array}{c}\mathrm{VO}_{2 \max }, \\
\mathrm{M} \cdot \mathrm{XB}^{-1} \cdot \mathrm{K}^{-1}\end{array}$ & $\begin{array}{l}38,25 \\
\pm 0,81\end{array}$ & $\begin{array}{l}39,72 \\
\pm 0,77\end{array}$ & $\begin{array}{c}41,47 \\
\pm 0,58 * *\end{array}$ & $\begin{array}{c}43,06 \\
\pm 0,85^{* *}\end{array}$ \\
\hline $\begin{array}{l}\text { МКЗМР, } \\
\text { кгм хв }{ }^{-1}\end{array}$ & $\begin{array}{c}1137,51 \\
\pm 60,69\end{array}$ & $\begin{array}{c}1201,51 \\
\pm 59,13\end{array}$ & $\begin{array}{c}1247,81 \\
\pm 63,86\end{array}$ & $\begin{array}{c}1293,94 \\
\pm 63,97\end{array}$ \\
\hline 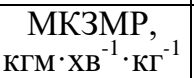 & $\begin{array}{l}18,15 \\
\pm 0,87\end{array}$ & $\begin{array}{c}19,47 \\
\pm 0,8\end{array}$ & $\begin{array}{l}20,33 \\
\pm 0,84\end{array}$ & $\begin{array}{l}21,19 \\
\pm 0,77\end{array}$ \\
\hline Маса тіла, кг & $62,77 \pm 2,51$ & $61,85 \pm 1,76$ & $61.46 \pm 2,51$ & $61,08 \pm 2,34$ \\
\hline
\end{tabular}

Примітка: вірогідність відмінності показника відносно вихідних даних: ** $\mathrm{P}<0,01 ; * * *-\mathrm{P}<0,001$

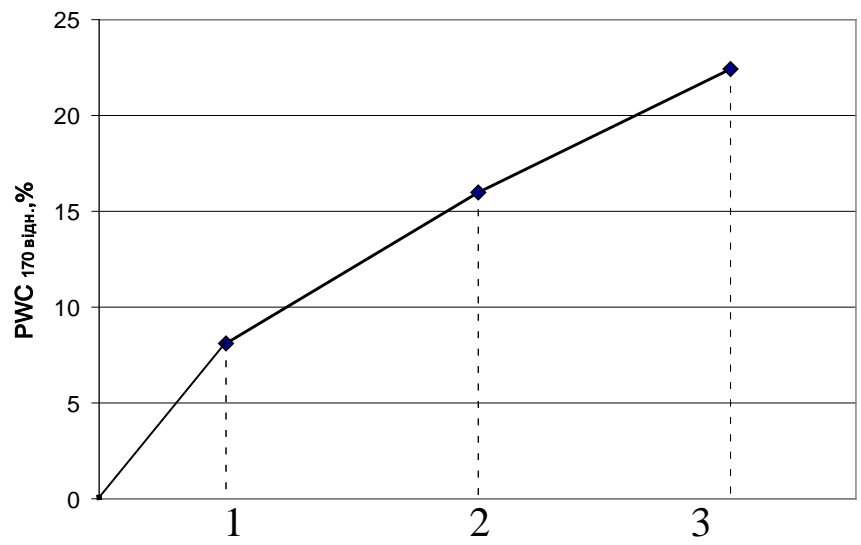

Рис. 8. Динаміка змін середньої величини $\mathrm{PWC}_{170 \text { відн. }}$ під впливом занять за модулем IV дівчат, у \% відносно вихідного рівня: 
1 - через 8 тижнів від початку занять; 2 - через 16 тижнів від початку занять; 3 - через 32 тижні від початку занять

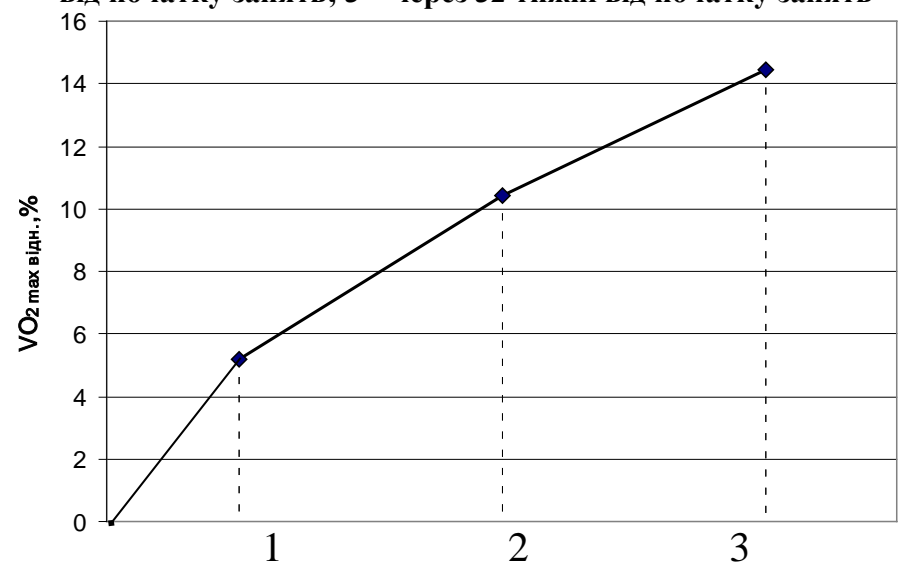

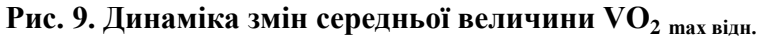
під впливом занять за модулем IV у дівчат, у \% відносно вихідного рівня:

1 - через 8 тижнів від початку занять; 2 - через 16 тижнів від початку занять; 3 - через 32 тижні від початку занять

Відносні показники $\mathrm{PWC}_{170}$ та $\mathrm{VO} 2$ max зросли відповідно на 23\% $(\mathrm{P}<0,01)$ та $12,58 \%(\mathrm{P}<0,01)$.

У результаті стимуляції анаеробних процесів енергозабезпечення у юнаків та дівчат, які займалися за відповідними модулями (III та IV), відбулося швидке зростання показників $\mathrm{PWC}_{170}$ i $\mathrm{VO}_{2 \max }$ незалежно від статі. Варто зазначити, що, на відміну від юнаків, у дівчат середні показників анаеробної (лактатної) продуктивності за показником МКЗМР вірогідно не змінились.

\section{ВИСНОВКИ}

Серед науковців відсутня єдність думок стосовно поширеності порушення постави серед студентів закладів вищої освіти. Значна поширеність порушення постави серед студентської молоді зумовлена недостатнім рівнем організаційної роботи у закладах вищої освіти, відсутністю чітких науково-методичних рекомендацій 3 фізичного виховання, низькою мотивацією до занять фізичною культурою через незадовільне формування потреби до рухової активності. Негативний вплив порушення постави проявляється не лише погіршенням функцій опорно-рухового апарату, але й зниженням фізичної та функціональної підготовленості студентів. 
Запропонована програма проводилася відповідно до критеріїв ефективності. У студентів зі сколіотичною поставою, які займались за аеробним та анаеробним модулями, відбулися позитивні зміни у рівні стану біогеометричного профілю постави. Так, серед студентів, які займались за аеробним модулем, $16,8 \%$ студентів перейшли на середній рівень і 8,4\% - на високий, у студенток $10 \%$ перейшли на середній рівень. Серед студентів, які займались анаеробним модулем, спостерігались такі зміни: 12,5\% студентів перейшли на середній рівень і $12,5 \%$ - на високий, а у студенток $15,4 \%$ - перейшли на середній рівень та 7,7\% - на високий. У студентів, які займались за типовою програмою закладів вищої освіти, спостерігалось погіршення, яке проявлялось у зниженні рівня стану біогеометричного профілю постави.

Фізичні навантаження із застосуванням модулів в аеробному режимі енергозабезпечення позитивно впливають на фізичну підготовленість студентів з порушенням постави незалежно від статі. У юнаків через 16 тижнів від початку занять за модулем I покращились показники загальної витривалості, швидкісної витривалості, силової статичної витривалості м'язів спини та сідничних м'язів. Заняття в такому режимі у дівчат також позитивно впливають на розвиток вищевказаних рухових якостей, окрім швидкісної витривалості. У юнаків відносний показник $\mathrm{VO}_{2 \max }$ зріс через 16 тижнів на $4,48 \%(\mathrm{p}<0,05)$, а у дівчат через 32 тижні на $6,84 \%(\mathrm{p}<0,05)$. Рівень аеробної продуктивності за критеріями Я.П. Пярната у юнаків до початку експерименту відповідав «низькому», а після завершення - «нижче посереднього». У дівчат рівень аеробної продуктивності до початку і після завершення формувального експерименту відповідав рівню «відмінно».

\section{АНОТАЦІЯ}

Для корекції функціональної підготовленості студентів 3 порушенням постави доцільно застосовувати фізичні вправи в аеробному i анаеробному (змішаному) режимах енергозабезпечення. Стимуляція анаеробних процесів енергозабезпечення під час занять зі студентами, які мають порушення постави, незалежно від статі, вірогідно покращує потужність анаеробних (лактатних) процесів енергозабезпечення за показниками максимального споживання кисню та аеробних процесів енергозабезпечення (за показниками МКЗМР). У студенток під впливом занять у змішаному режимі енергозабезпечення через 8 тижнів середні

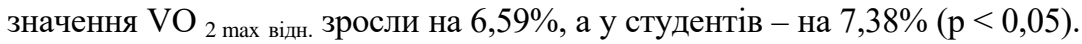
Через 8 тижнів від початку занять цей показник порівняно з вихідними значеннями зріс у дівчат на $13,26 \%$, а у юнаків - на $16,86 \%$. 
До початку занять рівень аеробної продуктивності за критеріями Я.П. Пярната у досліджуваних дівчат був «відмінний», тоді як у юнаків - «нижче посереднього».

У студенток рівень аеробної продуктивності не змінився протягом усього періоду формувального експерименту і відповідав «відмінному», а у студентів через 16 тижнів покращився до «посереднього». Заняття сприяли підвищенню анаеробної продуктивності організму юнаків за показниками максимальної кількості зовнішньої механічної роботи за одну хвилину (МКЗМР), яка характеризує анаеробні (лактатні) можливості організму.

Ключові слова: фізична працездатність, студенти, постава, аеробні навантаження.

\section{ЛІТЕРАТУРА}

1. Альошина А., Колос М. Корекція функціональних порушень опорно-рухового апарату студентів у процесі фізичного виховання. Фізичне виховання, спорт і культура здоров'я у сучасному суспільстві : зб. наук. пр. Східноєвроп. нац. ун-ту ім. Лесі Украӥнки / уклад. А.В. Цьось, С.П. Козіброцький. Луцьк : Східноєвроп. нац. ун-т ім. Лесі Українки, 2015. № 4(32). С. 52-56.

2. Апанасенко Г.Л. О возможности количественной оценки здоровья человека. Гигиена и санитария. 1985. № 6. С. 55-58.

3. Дудко М.В. Характеристика состояния биогеометрического профиля осанки и физической подготовленности студентов в процессе физического воспитания. Физическое воспитание студентов. 2015. 0;4. C. $30-35$

4. Кашуба В.А., Носова Н.Л., Дудко М.В., Одноралова Н.А. Визуальный скрининг биогеометрического профиля осанки студентов в процессе физического воспитания. Сучасні біомеханічні та інформаційні технології у фізичному вихованні $і$ спорті : матеріали III Всеукр. електронної конф. : (Київ, 18 червня 2015 р.). Київ : НУФВСУ, 2015. С. 72-76.

5. Кашуба В.А., Футорный С.М., Андреева Г.В., Рудницкий А.В. Скрининг показателей физического здоровья студентов в процессе физического воспитания. Теория и методика физ. культуры. Алматы, № 4. C. $65-74$.

6. Куц-Бурдейна О. Вплив бігових навантажень на функціональну підготовленість студенток з порушенням постави / Олександра Куц-Бурдейна, Юрій Фурман. Спортивна наука України. 2017. № 1(77). С. 38-42.

7. Лопацький С.В., Випасняк І.П., Вінтоняк О.В. Аналіз корекційно-профілактичних технологій, використовуваних у процесі фізичного виховання студентів 3 функціональними порушеннями 
опорно-рухового апарату. Вісник Прикарпатського університету. Серія : Фізична культура. 2016. Вип. 23. С. 3-11.

8. Мартынюк О.А. Обоснование технологии мониторинга пространственной организации тела студентов в процессе физического воспитания. Фізичне виховання, спорт і культура здоров'я у сучасному суспільстві. Луцьк : Волин, нац. ун-т ім. Л. Українки, 2009. № 4(8). С. 49-53.

9. Пярнат Я.П. Возрастно-половые стандарты (10-50 лет) аэробной способности человека : автореф. дис.... д-ра мед. Паук : 03.00.13 / Центральный гос. ин-т. физ. к-ры. Москва, 1983, 44 с.

10. Скрининг показателей физического здоровья студентов в процессе физического воспитания / В.А. Кашуба, С.М. Футорный, Е.В. Андреева, А.В. Рудницкий. Теория и методика физ. культуры. Алматы, 2012. № 4. С. 65-74.

11. Футорний С.M. Теоретико-методичні основи інноваційних технологій формування здорового способу життя студентів в процесі фізичного виховання : автореф. дис. на здобуття наук, ступеня д-ра наук 3 фіз. виховання і спорту : спец. 24.00.02 «Фізична культура, фізичне виховання різних груп населення». Київ, 2015. 43 с.

\section{Information about author:} Kuts-Burdeina O. O., Candidate of Training and Sport, Vinnytsia Institute of the Open International University of Human Development "Ukraine" 23-a, Khmelnytske shose str., Vinnitsa, 21000, Ukraine 